\title{
Masalah Kemanusiaan hingga Lingkungan Hidup: Studi Kasus Konflik Nagorno- Karabakh (Azerbaijan Vs Armenia)
}

Hanna Arinawati; Fathimah Azzahrah Putri; Shereena El Islamy Fakultas Hukum Universitas Indonesia

*Corresponding Author : hannaarinawati@gmail.com

$\begin{array}{ll}\text { Submission } & : 12 \text { Juli } 2021 \\ \text { Revision } & : 06 \text { September } 2021 \\ \text { Publication } & : 12 \text { Oktober } 2021\end{array}$

\begin{abstract}
Armed conflict in a war is recognized as one way to resolve disputes between countries. However, armed conflict has negative impacts on humanity and the environment. This study discusses the conflict between Azerbaijan and Armenia which resulted in the deaths of 150 civilians and 5000 soldiers died and had a negative impact on the environment. Azerbaijan was accused that in this war it used White Phosphorus or fireworks with white smoke which carries a very dangerous chemical, it can cause disability or the extinction of wildlife forever. Meanwhile, the Armenians exploited the natural resources of the occupied territories without considering the superiority of population interests and changes in regional cultural heritage. The results showed that in the Nagorno-Karabakh conflict 2020 (Azerbaijan vs. Armenia) there were violations of international agreements in international environmental law and international humanitarian law that occurred as a result of the conflict which could be held accountable internationally. Then in relation to accountability due to armed conflict, Armenia and its affiliates in the occupied territory of Azerbaijan are responsible for acts of international violations.
\end{abstract}

Keywords: armed conflict; environment; humanity 


\begin{abstract}
Abstrak
Konflik bersenjata dalam sebuah perang diakui menjadi salah satu cara untuk menyelesaikan sengketa antar negara. Namun, konflik bersenjata menimbulkan dampak negatif terhadap kemanusiaan dan lingkungan. Penelitian ini membahas mengenai konflik antara Azerbaijan dan Armenia yang mengakibatkan adanya korban jiwa 150 warga sipil tewas dan 5000 tentara tewas dan memiliki dampak buruk terhadap lingkungan. Azerbaijan mendapat tuduhan bahwa dalam perang ini pihaknya menggunakan White Phosphorus atau kembang api dengan asap putih yang membawa bahan kimia yang sangat berbahaya, dapat mengakibatkan cacat tubuh maupun kepunahan margasatwa selamanya. Sedangkan pihak Armenia melakukan eksploitasi sumber daya alam wilayah pendudukan tanpa mempertimbangkan keunggulan kepentingan populasi dan perubahan cagar budaya daerah. Hasil penelitian menunjukkan bahwa pada konflik Nagorno-Karabakh 2020 (Azerbaijan vs Armenia) terlihat adanya pelanggaran perjanjian internasional dalam hukum lingkungan internasional dan hukum humaniter internasional yang terjadi akibat konflik tersebut yang dapat dimintakan pertanggung jawaban secara internasional. Kemudian dalam kaitannya dengan pertanggungjawaban akibat konflik bersenjata, Armenia dan afiliasinya di wilayah pendudukan Azerbaijan bertanggung jawab atas tindakan pelanggaran internasional.
\end{abstract}

Kata Kunci: konflik bersenjata; lingkungan; kemanusiaan

\title{
A. Pendahuluan
}

Kemampuan suatu negara dalam menjalin hubungan dengan negara lain pada saat ini tentunya memiliki makna yang penting bagi sebuah negara. Hal tersebut mencerminkan bahwa mereka telah memiliki kecakapan dalam menjaga integritas teritorialnya. Kemampuan tersebut pun dinilai dapat menciptakan persamaan kedudukan dan derajat antar masingmasing negara, dan juga sebagai bukti adanya kemerdekaan 
dan kedulatan yang dimiliki oleh suatu negara. ${ }^{1}$ Dalam suatu pergaulan masyarakat internasional, tidak menjadi hal yang asing lagi apabila negara-negara selalu mengadakan hubungan satu sama lainnya, hubungan ini didasarkan atas kepentingan negara masing-masing. Kepentingan yang dimaksud meliputi antara lain, kepentingan ekonomi, hukum, pendidikan, sosial budaya, dan sebagainya. ${ }^{2}$ Adanya hubungan yang tetap dan terus menerus ini merupakan salah satu unsur dari eksistensi masyarakat internasional. ${ }^{3}$ Artikel ini mencoba membahas bagaimana persoalan mekanisme dalam penanggalan kekebalan (immunity waiver) oleh negara pengirim terhadap pejabat diplomatik.

Hubungan antara satu negara dengan negara yang lain, tidak selamanya berjalan dengan baik dikarenakan dapat timbul adanya perbedaan ideologi, keinginan untuk memperluas kekuasaan dari suatu negara, perbedaan kepentingan dan perampasan sumber daya alam ${ }^{4}$. Hal ini dapat menimbulkan sengketa dalam hubungan antar negara yang

1 Hanna Safira Nasution. Penyalahgunaan Wewenang Oleh Pejabat Diplomatik Dalam Melaksanakan Tugas Diplomatiknya Ditinjau Dari Aspek Hukum Internasional. Jurnal Ilmu Hukum, 2017, hal. 4.

2 Mochtar Kusumaatmadja dan Etty R. Agoes, Pengantar Hukum Internasional. Edisi Ke-2. Bandung: PT. Alumni. 2003. hal. 12.

3 Masyarakat Internasional merupakan suatu kompleks kehidupan bersama yang terdiri dari aneka ragam masyarakat yang jalinmenjalin dengan erat. Ibid., hal.13.

4 Daniel S. Papp. Contemporary International Relations : Frameworks for Understanding. Macmillan. 1988. hal 147.

Uti Possidetis: Journal of International Law, Vol. 2, No. 3 (2021) 
Masalah Kemanusiaan hingga Lingkungan Hidup...

berwujud pada terjadinya peperangan. ${ }^{5}$ Mochtar Kusumaatmadja dalam bukunya menyatakan bahwa merupakan kenyataan yang menyedihkan bahwa selama 3400 tahun sejarah yang tertulis, umat manusia hanya mengenal 2500 tahun perdamaian. ${ }^{6}$

Penggunaan kekuatan bersenjata dalam perang diakui sebagai salah satu cara penyelesaian sengketa internasional, selain dengan menggunakan penyelesaian sengketa internasional melalui cara berdamai. Konflik bersenjata akan terjadi apabila negara-negara saling bertentangan dan merasa bahwa tujuan-tujuan eksklusif mereka tidak bisa dicapai, kecuali melalui cara-cara kekerasan. ${ }^{7}$ Penggunaan senjata dalam peperangan tidak sebatas hanya dalam penggunaan peluru atau bahan ledakan. Namun, dimungkinkan bagi negara tersebut menggunakan senjata yang dapat memusnahkan serta mengandung zat kimia yang dapat berdampak buruk bagi kehidupan manusia serta lingkungannya. Dalam hal ini, manusia bisa saja kehilangan nyawanya secara langsung karena menjadi korban akibat peperangan yang sedang terjadi. Aktivitas peperangan seperti ini akan berdampak pada lingkungan sebagai media, dimulai dari ketika dilakukannya

5 Huala Adolf. Hukum Penyelesaian Sengketa Internasional. Jakarta: Sinar Grafika. Cetakan ketiga. 2008. hal 1.

6 Mochtar Kusumaatmadja. Konvensi-Konvensi Palang Merah 1949. Bandung : PT Alumni. 2002. hal. 11.

7 Ambarwati, Denny Ramdhany dan Rina Rusman. Hukum Humaniter Internasional Dalam Studi Hubungan Internasional. Jakarta: Raja Grafindo Persada. 2012. hal 2. 
pembuatan, percobaan, pemeliharaan dan penggunaan senjatasenjata perang, baik senjata yang konvensional, senjata kimia, biologi serta senjata nuklir yang mengandung racun berbahaya serta zat radioaktif. ${ }^{8}$

Pasal 2 Ayat (3) Piagam PBB yang menyatakan "All members shall settle their international disputes by peaceful means in such a manner that international peace and security are not endangered." Piagam tersebut menghendaki penyelesaian sengketa dengan cara-cara yang damai serta tidak membahayakan keamanan dunia. Meskipun perang akan membawa suatu kesengsaraan dalam berbagai aspek kehidupan manusia, perang juga diakui sebagai suatu mekanisme dalam penyelesaian sengketa dalam hukum Internasional.

Dalam pembahasan kali ini, kami akan membahas mengenai perlindungan lingkungan hidup dalam situasi konflik bersenjata dengan mengambil studi kasus Perang Azerbaijan dengan Armenia yang terjadi kembali pada baru-baru ini pada Juli 2020. Yang mana kasus ini menjadi perhatian internasional dikarenakan perang ini berdampak pada kerusakan lingkungan serta juga memakan korban. Selain itu, kerusakan yang terjadi akibat perang ini juga berdampak pada lingkungan manusia pasca perang tersebut.

8 Sri Wartini. Perlindungan Lingkungan dalam Hukum Humaniter. Jurnal Hukum Ius Quia Iustum, 2003. hal 151.

Uti Possidetis: Journal of International Law, Vol. 2, No. 3 (2021) 
B. Pembahasan

\section{Perlindungan Lingkungan Hidup oleh Hukum Humaniter Internasional}

Hukum humaniter internasional merupakan satu bagian dari hukum internasional yang diterapkan pada waktu pertikaian bersenjata. Tujuan hukum humaniter internasional adalah menjamin penghormatan manusia dalam batas keperluan militer dan ketertiban umum, serta mengurangi akibat-akibat permusuhan. ${ }^{9}$ Selain itu, hukum humaniter internasional merupakan cabang dari hukum internasional yang mengatur tentang perlindungan korban perang dan mengatur tentang penggunaan alat dan cara berperang. ${ }^{10}$ Hubungan antara hukum lingkungan internasional dengan hukum humaniter internasional merupakan hubungan horizontal antar dua cabang hukum internasional. Selama ini pembahasan perlindungan lingkungan dalam konflik bersenjata dilakukan terpisah antara hukum lingkungan internasional dengan hukum humaniter internasional. ${ }^{11}$

a. Perjanjian Internasional

9 Sulaiman. Sengketa Bersenjata Non-Internasional. Jurnal Hukum dan Pembangunan 2000. hal. 24.

10 Sulaiman. "Sengketa Bersenjata...", hal. 23.

11 J. Wyatt. Law Making at the Intersection of International Environmental Law, Humanitarian Law, and Criminal Law: The Issue of Damage to The Environment in International Armed Conflict. International Review of the Red Cross. 2010. hal 594.

Uti Possidetis: Journal of International Law, Vol. 2, No. 3 (2021) 
1. The 1976 Convention on the Prohibition of Military or Any Other Hostile Use of Environmental Modification Techniques (ENMOD 1976)

Kepedulian manusia terhadap lingkungan hidup dalam situasi konflik bersenjata mulai terbuka saat meletusnya peristiwa Perang Vietnam yang berlangsung pada tahun 1955 hingga tahun 1975 sehingga dibentuklah Environmental Modification Convention (ENMOD) dibuat pada tahun 1976 yang berisi larangan para pihak untuk menggunakan caracara dan persenjataan serta teknik-teknik modifikasi lingkungan yang bertujuan untuk menimbulkan kerusakan atau penderitaan yang mendalam kepada pihak lain.

Pasal 1 ayat (1) ENMOD 1976 mensyaratkan bahwa setiap negara pihak kepada Konvensi ini berjanji untuk tidak terlibat dalam militer atau penggunaan lain dari modifikasi lingkungan yang tidak bersahabat teknik yang tersebar luas, tahan lama atau parah efek sebagai sarana penghancuran, kerusakan atau cedera kepada negara pihak lainnya. Konvensi ini mendefinisikan teknik modifikasi lingkungan sebagai "any technique for changing - through the deleberate manipulation of natural processes the dynamics composition or structure of the Earth, including its biota, 
lithosphere, hydrosphere and atmosphere, or of outer space". ${ }^{12}$

2. Additional Protocol I to the Geneva Conventions of 12 August 1949 (1977)

Protokol Tambahan I dan II ke Konvensi Jenewa terjadi dengan latar belakang berbagai perang, termasuk Perang Vietnam yang menimbulkan pertanggungjawaban serius tentang perlindungan populasi sipil dan lingkungan. Pertumbuhan kesadaran lingkungan, serta kekhawatiran atas taktik militer yang digunakan selama perang ini, menyebabkan inklusi dua ketentuan dalam Protokol Tambahan I yang secara eksplisit membahas bahaya lingkungan yakni Pasal 35 ayat (3) dan Pasal 55 yang melarang aktivitas konflik bersenjata yang mengakibatkan kerusakan yang parah, meluas, atau berkepanjangan terhadap lingkungan hidup.

3. Convention on Prohibitions or Restrictions on the Use of Certain Conventional Weapons Which May be Deemed to be Excessively Injurious or to have Indiscriminate Effects (CCW 1980)

Konvensi ini juga dikenal sebagai Konvensi tentang Senjata Konvensional Tertentu dan Konvensi Senjata Tidak Manusiawi yang menyatakan dalam Pembukaannya bahwa: "it is prohibited to employ

12 United Nations General Assembly, Convention on The Prohibition of Military or Any Other Hostile of Environmental Modification Techniques (1976), Ps. 2.

Uti Possidetis: Journal of International Law, Vol. 2, No. 3 (2021) 
methods or means of warfare which are intended, or may be expected, to cause widespread, long-term and severe damage to the natural environment". ${ }^{13}$ Selanjutnya, Pasal 2 (4) Protokol III CCW 1980 tentang Larangan atau Batasan Penggunaan Senjata Pembakaran juga secara langsung mengatur mengenai perlindungan lingkungan dalam situasi konflik bersenjata.

4. Convention (IV) respecting the Laws and Customs of War on Land and its annex: Regulations concerning the Laws and Customs of War on Land. The Hague (Den Haag Convention IV 1907)

Terdapat dua ketentuan dari Konvensi Den Haag IV tahun 1907 mengatur mengenai penggunaan senjata di dalam konflik bersenjata yang relevan untuk melindungi lingkungan, yaitu pasal 22 dan 23.14

5. Protocol for the Prohibition of the Use in War of Asphyxiating, Poisonous or other Gases, and of Bacteriological Methods of Warfare 1925 (Geneva Protocol)

Protokol ini mengatur larangan penggunaan senjata kimia dan biologi dalam konflik bersenjata Internasional. Konvensi tersebut ditandatangani pada tanggal 17 Juni 1925 di Jenewa dan mulai berlaku pada tanggal 8 Februari 1928.

6. Convention for the Protection of Cultural Property in the Event of Armed Conflict 1954 (Hague Convention)

13 Convention on Prohibitions or Restrictions on the Use of Certain Conventional Weapons Which May be Deemed to be Excessively Injurious or to have Indiscriminate Effects. Geneva: ICRC. 2004. hal. 11.

14 David Jensen dan Silja Halle. Protecting the Environment..., hal. 14. 
Dalam konvensi ini, dijelaskan mengenai Perlindungan Benda Budaya pada waktu konflik bersenjata, serta memberikan pengaturan tentang upaya waktu damai untuk mencegah dampak konflik terhadap benda budaya. Dilanjut pada protokol kedua Convention for the Protection of Cultural Property in the Event of Armed Conflict tahun 1999, memuat mengenai langkah konkrit dalam persiapan inventarisasi, perencanaan langkah darurat untuk kebakaran dan runtuhnya bangunan, persiapan bagi pemindahan atau pun pengembalian dan pembentukan otoritas berwenang terhadap penjagaan benda budaya dalam konflik bersenjata. ${ }^{15}$

b. Prinsip-Prinsip Umum Hukum Humaniter Internasional

Dalam hukum humaniter internasional terdapat beberapa prinsip, diantaranya adalah Prinsip Pembedaan (Distinction Principle), Prinsip Pembatasan Senjata (Limitation Principle), Prinsip Proporsionalitas, Prinsip Diskriminasi, dan Prinsip Memperhatikan Lingkungan.

15 Eka Martiana Wulansari. Perlindungan Hukum Benda Budaya Dari Bahaya Konflik Bersenjata. Disertasi. Universitas Pamulang. 2016. hal. 370 . 


\section{Perlindungan Lingkungan Hidup oleh Hukum Lingkungan Internasional}

Perlindungan lingkungan hidup dalam konflik bersenjata tidak cukup apabila hanya dilakukan dengan hukum humaniter saja karena hukum lingkungan internasional-lah yang dapat memahami lingkungan hidup yang sebenar-benarnya. Prinsipprinsip dasar perlindungan, pendekatan, norma, dan mekanisme perlindungan lingkungan hanya dapat ditemukan di hukum lingkungan internasional. ${ }^{16}$ Hukum lingkungan internasional dapat memperkuat hukum humaniter internasional dalam mencegah lingkungan hidup agar tidak menjadi korban konflik bersenjata sehingga perlindungan lingkungan hidup dalam konflik bersenjata, dapat diterapkan lebih spesifik. ${ }^{17}$

a) Prinsip 23, 24, 25, \& 26 Rio Declaration

Dalam dua puluh tujuh prinsip yang terdapat dalam Deklarasi Rio, terdapat empat prinsip yang berkaitan dengan perlindungan lingkungan hidup dalam konflik bersenjata yakni pada prinsip ke 23, ke 24, ke 25, dan ke 26 .

b) Stockholm Convention on Persistent Organic Pollutants 2001

Stockholm Convention on Persistent Organic Pollutants yang diadopsi pada tahun 2001 menjadi panduan utama dalam penggunaan senyawa kimia sebagai senjata dalam perang. Pasal 1 konvensi ini mengatur bahwa "Mindful of the

\footnotetext{
16 Michael Bothe, et.al. International Law. hal. 569.
}

17 Ibid.

Uti Possidetis: Journal of International Law, Vol. 2, No. 3 (2021) 
precautionary approach as set forth in Principle 15 of the Rio Declaration on Environment and Development, the objective of this Convention is to protect human health and the environment from persistent organic pollutants." Ketentuan dalam hukum internasional terkait dengan larangan penggunaan senjata kimia dalam keadaan perang telah menjadi hal yang diakui bersama oleh mayoritas masyarakat hukum internasional.

Dalam hukum internasional, secara jelas menjelaskan bahwa terdapat keinginan dalam penerapan prinsip kehatihatian antara konflik bersenjata dengan lingkungan hidup. Akan terdapat banyak dampak yang diberikan yang diakibatkan oleh sebuah operasi militer yang tidak dapat dipastikan bahwa pihak-pihak terkait akan diberikan kebebasan dalam melakukan tindakan kehati-hatian serta pihak tersebut dimungkinkan akan meninggalkan kewajibannya dalam melindungi lingkungan hidup pada saat sebuah konflik sedang terjadi. Pernyataan Mahkamah Internasional yang berbunyi "The environment is not an abstraction but represents the living space, the quality of life and the very health of human beings, including generations unborn"18 diakui bahwa perlindungan lingkungan hidup tergolong ke dalam aspek yang perlu diperhatikan. Dalam pengaplikasian prinsip maxim sic utero tuo

18 Yoram Dinstein. Protection of the Environment in International Armed Conflict. Max Planck Yearbook of United Nations Law, Volume 5. 2001. hal. 523. 
ut alienum laodas, negara-negara diwajibkan untuk tidak merusak lingkungan hidup negara orang lain ketika sedang sedang berperang.

Selain itu, Mahkamah Internasional juga memiliki prinsip lain yakni necessity and proportionality yang ada dalam hukum lingkungan internasional dan konflik bersenjata. Prinsip ini menyatakan bahwa "States must take environmental considerations into account when assessing what is necessary and proportionate in the pursuit of legitimate military objectives. Respect for the environment is one of the elements that go to assessing whether an action is in conformity with the principles of necessity and proportionality." . Proporsional yang dimaksud dalam hal ini adalah bentuk kerusakan yang timbul nantinya tidak boleh melampaui batas dari target militer yang diharapkan dan tidak boleh lebih besar dari keuntungan yang didapatkan ${ }^{19}$.

Sebagai penegasan mengenai perlindungan lingkungan dalam masa perang adalah, jika kita lihat prinsip hukum konflik bersenjata, hukum internasional terutama yang mengatur mengenai perlindungan lingkungan akan ditangguhkan pengaplikasiannya ketika perang berlangsung dan hanya berlaku ketika masa damai dan menjadi satu perjanjian masa damai "peacetime agreement". Namun, perspektif ini dianggap terlalu sempit, karena jika dilihat dari hukum internasional

19 Yoram Dinstein. Protection, hal. 24.

Uti Possidetis: Journal of International Law, Vol. 2, No. 3 (2021) 
modern mengakui bahwa hukum internasional yang berlaku selama konflik bersenjata berlangsung akan lebih luas implementasinya daripada hukum konflik bersenjata, terutama dalam hal perlindungan lingkungan. Karena pada masa perang pelanggaran yang dapat terjadi bukan hanya mengenai humaniter saja tetapi lingkungan juga terdampak maka hukum yang berlaku kaitannya dengan konflik bersenjata jika hanya menggunakan hukum konflik bersenjata saja yang merujuk pada hukum humaniter sebagai lex specialis akan tidak cukup untuk menemukan solusinya, dibutuhkan hukum internasional lainnya seperti hukum mengenai hak asasi manusia dan hukum lingkungan internasional. Jika ditarik kesimpulan, bahwa perjanjian atau hukum internasional akan tetap beroperasi meskipun perang berlangsung. ${ }^{20}$

\section{Kasus}

Pada tahun 2020, Azerbaijan terlibat konflik bersenjata dengan negara jirannya yakni Armenia. Lokasi terjadinya konflik tersebut berada di wilayah Nagorno-Karabakh (sekarang dikenal dengan Republik Artsakh). Pertempuran ini berlangsung selama 6 minggu (27 September 2020-10 November 2020) dan dalam kurun waktu tersebut sebelum terjadi gencatan senjata yang ditengahi oleh Rusia,

20 Marie G. Jacobsson. International Law Commision: Preliminary report on the protection of the environment in relation to armed conflicts. 2014. hal 2-3.

Uti Possidetis: Journal of International Law, Vol. 2, No. 3 (2021) 
mengakibatkan korban jiwa 150 warga sipil tewas dan 5000 tentara tewas, dengan 130.000 orang mengungsi ke Armenia. Dalam perjalanan konflik ini, kedua negara saling melempar propaganda tuduhan mengenai siapa yang benar-benar melakukan perusakan lingkungan saat terjadinya konflik ini di Artsakh.

Propaganda mengenai tuduhan siapa yang melakukan perusakan lingkungan ini sangat kuat disuarakan melalui media sosial, baik oleh akun masyarakat sipil, para pasukan maupun oleh akun resmi sosial media milik negara. Cuitan-cuitan tersebut banyak yang membahas bahwa perusakan lingkungan yang terjadi dalam konflik bersenjata dua negara ini adalah terjadinya suatu Ecocide atau kepanjangannya dari Eco Genocide. Ecocide adalah istilah dari pemusnahan lingkungan dan dinilai sebagai bentuk kejahatan berat yang memiliki dampak buruk yang sangat luas bagi kehidupan manusia maupun makhluk hidup lainnya yang berada di wilayah Ecocide tersebut. ${ }^{21}$ Dalam kasus ini terjadi tuduh menuduh mengenai penggunaan bahan dalam perang serta perilaku pengrusakan lingkungan dalam perang. Azerbaijan mendapat tuduhan bahwa dalam perang ini pihaknya menggunakan White Phosphorus atau kembang api dengan asap putih yang membawa bahan kimia yang sangat berbahaya, dapat

21 Hizbullah Arief. Mengurai "Ecocide" untuk menyelamatkan Lingkungan? https://www.walhi.or.id/mengurai-ecocide-untukmenyelamatkan-lingkungan. diakses 31 Mei 2021. 
mengakibatkan cacat tubuh maupun kepunahan margasatwa selamanya. Sedangkan pihak Armenia mendapat tuduhan bahwa melalui video yang tersebar di sosial media menggambarkan orang-orang Armenia yang membakar sarang lebah dan pepohonan di hutan ketika melarikan diri dari Nagorno-Karabakh. Namun, perlu diingat bahwa tuduhan ini belum sepenuhnya terbukti. Terjadinya kesimpangsiuran informasi mengenai apa-apa saja yang telah terjadi adalah karena memang di Azerbaijan memiliki kebebasan dan ketidakberpihakan pers yang rendah. Sehingga sangat terlihat sekali bahwa lingkungan telah digunakan sebagai senjata propaganda oleh kedua belah pihak untuk mendapatkan kemenangannya.

Mengesampingkan mengenai siapa yang melakukan perusakan lingkungan, terdapat fakta yang menunjukkan adanya titik api di wilayah tutupan hutan Nagorno-Karabakh yang terdeteksi oleh instrumen Suomi-NPP VIIRS diantara tanggal 26 Oktober - 4 November dengan puncaknya yakni 31 Oktober. Dalam periode tersebut terdeteksi adanya 447 kebakaran yang muncul dengan luas wilayah yang terbakar untuk tingkat moderat dan berat seluas $102 \mathrm{~km} 2$. Jumlah kebakaran tersebut merupakan angka yang tertinggi daripada tahun-tahun sebelumnya sejak instrumen Suomi-NPP VIIRS diluncurkan pada tahun 2012. Akibat adanya kebakaran ini menyebabkan munculnya kabut asap yang bergerak ke arah timur dan timur laut Azerbaijan. Asap ini juga meningkatkan 
kadar karbon monoksida, nitrogen dioksida, metana, dan aerosol penyerap (karbon hitam). Disekitar titik munculnya api juga ditemui bahwa terdapat Formaldehid (Formalin) dengan kadar yang cukup tinggi. Asap kebakaran ini dapat menyebabkan masalah kesehatan yang akut bagi kelompok masyarakat rentan.

Dampak asap kebakaran juga dirasakan oleh keanekaragaman hayati baik secara langsung maupun untuk jangka panjang seperti rusaknya habitat karena terkontaminasi dari sisi-sisa bahan kimia berbahaya yang digunakan saat perang. Perekonomian juga salah satu bidang yang terkena dampak, dimana hutan menjadi mother source bagi penduduk sekitar hutan yang mata pencahariannya sangat bergantung pada kondisi hutan, dengan rusaknya hutan maka akan mengganggu stabilitas penghidupan mereka. Selain hutan, lahan pertanian juga menjadi titik kebakaran, dan dimungkinkan bahwa itu merupakan kerusakan tambahan. Melihat kembali penggabungan data titik-titik kebakaran yang mayoritas terjadi di hutan tertutup dengan peta penggunaan lahan, menguatkan teori hilangnya tutupan hutan untuk keuntungan militer terutama keuntungan udara.

\section{Pertanggungjawaban Armenia terhadap Konflik}

Penyelesaian sengketa di bawah pengawasan PBB ditentukan oleh tujuan dasar dari PBB dan kewajibankewajiban anggota-anggotanya. Salah satu tujuan dasar 
pembentukan PBB adalah penyelesaian sengketa secara damai atas sengketa antar negara. Adapun salah satu kewajiban anggota PBB adalah mereka harus menahan diri untuk mengancam perang atau menggunakan kekerasan. Peranan PBB dalam penyelesaian sengketa secara damai dapat dilakukan melalui penyelesaian secara politik dan hukum. Penyelesaian sengketa secara politik dilakukan oleh Majelis Umum dan Dewan Keamanan sedang penyelesaian sengketa secara hukum dilakukan oleh Mahkamah Internasional.

Dalam Pasal 1 Piagam PBB dijelaskan bahwa salah satu tujuan dari PBB adalah mengadakan tindakan bersama yang tepat untuk mencegah dan melenyapkan ancaman bagi perdamaian, dan karenanya setiap sengketa hendaknya diselesaikan dengan jalan damai sesuai dengan prinsip keadilan dan hukum internasional agar tidak mengganggu perdamaian.

Pasal 33 (1) UN Charter menjelaskan bahwa cara penyelesaian sengketa para pihak dapat dilakukan melalui

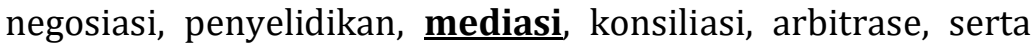
penyelesaian menurut hukum melalui badan atau pengaturan regional, atau cara damai lainnya yang dipilih sendiri.

Pada kasus ini, para pihak yaitu Azerbaijan dan Armenia sepakat untuk menyelesaikan sengketa secara mediasi dengan rusia sebagai mediatornya yang ditaungkan dalam suatu Perjanjian Perdamaian (The Statement by the President of the Republic of Azerbaijan, Prime Minister of the Republic of Armenia and President of the Russian Federation). 
Kemudian dalam kaitannya dengan pertanggungjawaban para pihak, di dalam perjanjian perdamaian tidak diatur mengenai siapa yang bertanggung jawab atas konflik bersenjata tersebut. Oleh karena itu berdasarkan hukum internasional bahwa pertanggungjawaban atas konflik tersebut dapat diselesaikan dengan menuntut Armenia ke hadapan Mahkamah Internasional untuk meminta tanggung jawab serta ganti kerugian yang ditimbulkan akibat agresi. Hal ini berdasar kepada Article 93 (1) UN Charter yang berbunyi All Members of the United Nations are ipso facto parties to the Statute of the International Court of Justice. Pasal ini menjelaskan bahwa semua anggota Perserikatan Bangsa-Bangsa adalah pihak ipso facto (secara nyata) Statuta Mahkamah Internasional). Oleh karena baik Azerbaijan dan Armenia merupakan negara anggota PBB maka masing-masing termasuk juga merupakan para pihak dari statuta Mahkamah Internasional.

Namun berdasarkan fakta bahwa Permanent Representative of Azerbaijan pada tanggal 3 Oktober 2017 bersurat kepada UN yang ditunjukkan kepada Sekjen PBB dengan merekomendasikan agar surat ini bisa menjadi Dokumen Majelis Umum di bawah agenda 35, 40, 70, 72 dan 84, dan Dewan Kemanan (sebagai dokumen yang mengikat secara hukum).

Selanjutnya menurut Pasal 2 ayat (4) Piagam PBB, integritas teritorial negara lebih penting daripada hak rakyat untuk menentukan nasib sendiri. Dalam hal ini, Piagam PBB 
berlaku untuk konflik Nagorno-Karabakh, sebagai integritas teritorial dari Azerbaijan dan tindakan agresi yang dilakukan oleh Armenia tidak dapat dibenarkan. Hal ini harus dipatuhi Armenia dikarenakan tatanan dunia didasarkan pada prinsipprinsip PBB dan ada dua dokumen utama yang mengikat secara hukum internasional (legally binding) adalah Piagam PBB dan resolusi Dewan Keamanan. Dalam bukunya Shaw menyatakan bahwa pasal antara lain melarang penggunaan kekerasan terhadap kedaulatan teritorial negara mana pun, mengacu pada 1949 Declaration of the Rights and Duties of the States, yang menyerukan tidak diakuinya perolehan wilayah yang diperoleh dengan menggunakan kekerasan atau cara lain yang tidak sesuai dengan prinsip-prinsip inti hukum internasional.

Kejahatan paling serius yang menjadi perhatian masyarakat internasional, seperti kejahatan perang, kejahatan terhadap kemanusiaan, genosida, pembersihan etnis dan kejahatan terhadap lingkungan telah dilakukan oleh pasukan Armenia selama agresi. Berbeda dengan pernyataan Armenia dan terlepas dari berbagai makalah yang beredar di Perserikatan Bangsa-Bangsa dan organisasi internasional lainnya atas nama rezim boneka yang telah didirikannya di wilayah pendudukan Azerbaijan, yang null dan void ab initio, ilegalitas rezim itu telah berulang kali dinyatakan di tingkat internasional dengan cara yang paling tidak ambigu. Berikut beberapa contohnya. 
Dalam resolusi Dewan Keamanan PBB 822 (1993), 853 (1993), 874 (1993) dan 884 (1993), UNSC mengutuk penggunaan kekuatan terhadap Azerbaijan, pemboman, pendudukan wilayahnya dan menegaskan kembali penghormatan terhadap kedaulatan dan keutuhan wilayah Azerbaijan, sifat internasional yang tidak dapat diganggu gugat perbatasan dan tidak dapat diterimanya penggunaan kekuatan untuk akuisisi wilayah. Dalam menanggapi klaim teritorial Armenia dan tindakan paksa, Dewan menegaskan kembali bahwa wilayah Nagorno-Karabakh merupakan bagian integral dari Azerbaijan dan menuntut penarikan pasukan pendudukan segera, lengkap dan tanpa syarat dari semua wilayah-wilayah yang diduduki. Dalam resolusi, Dewan Keamanan mengakui fakta bahwa tindakan kekuatan militer dilakukan terhadap Azerbaijan; bahwa tindakan tersebut melanggar hukum dan tidak sesuai dengan larangan penggunaan kekuatan bersenjata dalam hubungan internasional international dan bertentangan dengan Piagam Perserikatan Bangsa-Bangsa dan tujuannya; dan untuk itu mereka merupakan pelanggaran nyata terhadap kedaulatan dan integritas teritorial Azerbaijan.

Penting untuk dicatat bahwa Dewan Keamanan mengadopsi resolusinya setelah Penduduk Armenia di wilayah Nagorno-Karabakh yang dimiliki Azerbaijan secara sepihak mendeklarasikan "kemerdekaan", sehingga sangat jelas bahwa deklarasi tersebut tidak mengakibatkan hukum apapun. Banyak dokumen yang diadopsi oleh otoritas internasional 
lainnya organisasi dibingkai di sepanjang garis yang sama. Penolakan terus-menerus Armenia atas tanggung jawabnya atas agresinya terhadap Azerbaijan dan pendudukan yang melanggar hukum dan kehadiran militer di wilayah negara Azeri telah secara efektif diakhiri oleh Grand Chamber of European Court of Human Rights dalam keputusan penting (Merits) tanggal 16 Juni 2015 dalam kasus Chiragov dan lainnya v. Armenia. Pengadilan memenangkan para pemohon, yang merupakan enam warga Azerbaijan yang dipindahkan secara paksa dari distrik Lachyn yang diduduki Azerbaijan, mengakui pelanggaran terus-menerus oleh Armenia atas sejumlah hak mereka di bawah Convention for the Protection of Human Rights and Fundamental Freedoms.

Setelah memeriksa bukti-bukti yang diajukan, Mahkamah, antara lain, sampai pada kesimpulan:

- "Republik Armenia, melalui kehadiran militernya dan penyediaan peralatan dan keahlian militer, telah secara signifikan terlibat dalam Konflik Nagorno-Karabakh sejak dini";

- "Dukungan militer ini telah - dan terus menjadi menentukan bagi penaklukan dan kendali terus atas wilayah yang dipermasalahkan";

- Rezim separatis di wilayah tersebut "Bertahan karena kekuatan militer, dukungan politik, keuangan dan lainnya yang diberikan kepadanya oleh Armenia yang, 
akibatnya, melakukan kontrolyang efektifatas NagornoKarabakh dan wilayah sekitar...".22

Pengadilan juga mengonfirmasi kesimpulannya dari keputusan admissibility tanggal 14 Desember 2011, menurutnya entitas separatis "is not recognized as a State under international law by any countries or international organisations..." dan, "against this background, the invoked laws cannot be considered legally valid for the purposes of the Convention and the applicants cannot be deemed to have lost their alleged rights to the land in question by virtue of these laws ...".23

Akibatnya, rezim separatis yang didirikan oleh Armenia di pendudukan wilayah Azerbaijan pada akhirnya tidak lain adalah nyata-nyata sebuah agresi, diskriminasi rasial dan pembersihan etnis; rezim berada di bawah arahan dan kendali atas Armenia sehingga Armenia bertanggung jawab secara penuh atas konflik termasuk di dalamnya kerusakan dan ganti rugi yang telah ditimbulkan sebagai akibatnya. Mengenai upaya Armenia untuk mengubah nama geografis sebagian Wilayah Azerbaijan yang diakui secara internasional, ketidakabsahannya berasal dari keadaan yang jelas akan pelanggaran hukum internasional, Konstitusi dan undangundang Azerbaijan serta prinsip dan prosedur standarisasi

22 Chiragov and others v. Armenia, Grand Chamber of the European Court of Human Rights, Judgment (Merits) of 16 June 2015, application No. 13216/05, paras. 180, 183, 185, 186.

Ibid., paras. 148 dan 182.

Uti Possidetis: Journal of International Law, Vol. 2, No. 3 (2021) 
internasional nama geografis yang didirikan di dalam Perserikatan Bangsa-Bangsa. Kenyataannya, dengan mempropagandakan keberadaan rezim separatis boneka, Armenia menyangkal fakta dan dengan tegas menunjukkan pengabaian totalnya terhadap posisi komunitas internasional dan keengganannya untuk mematuhi norma dan prinsip hukum internasional.

Fakta menunjukkan bahwa orang Armenia muncul dalam apa yang mereka sebut sebagai "Ancestral homeland" hanya pada abad kesembilan belas. Pemindahan massal mereka selanjutnya di Kaukasus Selatan dan upaya perluasan wilayah telah menjadi dasar jangka panjang ketidakstabilan, ketegangan dan konflik di kawasan yang terus berlanjut hingga saat ini dan telah disertai dengan pembantaian dan deportasi paksa penduduk Azerbaijan. ${ }^{24}$

Tak satupun dari komitmen perlindungan cara-cara perang dan hak asasi manusia yang bersifat preferensial perlakuan untuk suatu negara, kelompok atau orang, atau dapat diartikan sebagai menyiratkan hak apapun untuk terlibat dalam aktivitas apa pun atau melakukan tindakan apapun yang

24 lihat the report entitled The Armed Aggression of the Republic of Armenia against the Republic of Azerbaijan: Root Causes and Consequences (A/64/475-S/2009/508), and the "Commentary to the remarks made by President Serzh Sargsyan of the Republic of Armenia at the Third International Forum of Moscow State Institute of International Relations Alumni", held on 23 October 2015 in Yerevan, Armenia. Available from www.mfa.gov.az/files/file/MFA Commentary to the remarks by Serzh Sargsyan.pdf. 
bertentangan dengan tujuan dan prinsip-prinsip Piagam Perserikatan Bangsa-Bangsa dan kewajiban lainnya berdasarkan hukum internasional, termasuk di dalamnya perlindungan terhadap lingkungan dan khususnya yang berkaitan dengan kedaulatan dan integritas teritorial negara. Perlu diingat pasal 29 (3) dari Universal Declaration of Human Rights, yang secara khusus mencatat bahwa "These rights and freedoms may in no case be exercised contrary to the purposes and principles of the United Nations". Pasal 30 dari Deklarasi Universal bahkan menegaskan kembali bahwa "Nothing in this Declaration may be interpreted as implying for any State, group or person any right to engage in any activity or to perform any act aimed at the destruction of any of the rights and freedoms set forth herein".

Common article 1.2 of the International Covenant on Economic Social and Cultural Rights and the International Covenant on Civil and Political Rights berfokus tentang "The principle of mutual benefit and international law", sedangkan pasal umum 5.1 dari kedua Kovenan menetapkan bahwa "Tidak ada dalam Kovenan ini yang dapat ditafsirkan sebagai menyiratkan untuk setiap Negara, kelompok atau orang hak untuk terlibat dalam kegiatan atau untuk melakukan tindakan apapun yang bertujuan untuk menghancurkan hak atau kebebasan yang diakui di sini, atau pada batasannya ke tingkat yang lebih besar daripada yang ditentukan di masa sekarang Perjanjian". Menurut pasal 24 dan 25 Konvensi Internasional 
tentang Hak Ekonomi Sosial dan Budaya dan pasal 46 dan 47 Internasional Konvensi tentang Hak Sipil dan Politik, "tidak ada apa pun dalam Kovenan ini yang akan ditafsirkan sebagai merusak ketentuan Piagam Perserikatan Bangsa-Bangsa..." dan..." “... Hak yang melekat pada semua orang untuk menikmati dan memanfaatkan secara penuh dan bebas akan kekayaan dan sumber daya alam".

Dengan mengutip pasal 9 of the Charter of Economic Rights and Duties of States, Armenia tidak menyebutkan bahwa dokumen yang sama menegaskan kembali, di antara fundamental prinsip-prinsip yang mengatur hubungan ekonomi antar negara, kedaulatan, teritorial integritas, kemerdekaan politik dan kesetaraan kedaulatan semua Negara, non-agresi dan non-intervensi. Piagam tersebut juga menekankan, dalam pasal 2, bahwa "setiap Negara memiliki dan harus bebas melaksanakan kedaulatan permanen penuh, termasuk kepemilikan, penggunaan dan pembuangan, atas semua kekayaan, sumber daya alam, dan kegiatan ekonominya".

Bukan kebetulan bahwa, dengan mengingat secara selektif provisions of the Charter of Economic Rights and Duties of States (article 9) and the Declaration on the Right to Development (article 3), yang menekankan kewajiban Negara untuk bekerja sama satu sama lain di berbagai bidang, Armenia gagal memberikan satu bagian dari bukti keberadaan setiap contoh sukses dari kerjasama semacam itu, di antaranya satu 
adalah agresor dan yang lainnya adalah objek agresi. Itu hanya menjadi omong kosong untuk negara yang wilayahnya di bawah pendudukan militer, yang ratusan ribuan warga menjadi sasaran kejahatan keji dan pembersihan etnis, untuk memberikan akses penyerang ke wilayahnya dan terlibat dengannya dalam segala hal hubungan ekonomi dan perdagangan terutama kerusakan lingkungan sebagai akibat dari agresi.

Sebagaimana ditegaskan kembali dalam Deklarasi dan Program Wina Aksi tahun 1993, "semua hak asasi manusia bersifat universal, tidak dapat dibagi dan saling bergantung dan saling berhubungan. Komunitas internasional harus memperlakukan hak asasi manusia secara global secara adil dengan cara yang setara, pada pijakan yang sama, dan dengan penekanan yang sama "(lihat A / CONF.157 / 24 (Bagian I), psl. III, paragraf. 5). Sebaliknya, setelah menerapkan "kebijakan bumi hangus", memenuhi syarat sebagai tidak dapat diterima dan dikutuk keras oleh Organisasi (saat itu Konferensi) karena Keamanan dan Kerjasama di Eropa, Armenia sekarang menolak bahkan untuk menerima keberadaan komunitas Azerbaijan di wilayah Nagorno-Karabakh Azerbaijan. ${ }^{25}$

Sebagai dasar argumen Armenia menggunakan pendapat Mahkamah terkait dengan kasus Afrika Selatan, tidak adanya pengakuan menyiratkan abstain dari hubungan perjanjian

25 CSCE Communication No. 301, Prague, 19 November 1993.

Uti Possidetis: Journal of International Law, Vol. 2, No. 3 (2021) 
tentang Namibia; penghentian "kerja sama antar pemerintah yang aktif" di bawah perjanjian bilateral yang ada terkait dengan Namibia; pantang dari semua kegiatan diplomatik atau konsuler di Namibia, dan, terutama, abstain dari "ekonomi" dan bentuk hubungan lain atau berurusan dengan Afrika Selatan atas nama atau terkait Namibia yang dapat memperkuat otoritasnya atas Wilayah".26 Dengan menyebut Pendapat Namibia, sebenarnya Armenia mengakui bahwa kesimpulan Pengadilan Internasional tersebut di atas dalam kasus tersebut dapat diterapkan oleh analogi dengan kebijakan dan praktiknya sendiri terkait dengan wilayah Nagorno-Karabakh dan wilayah pendudukan Azerbaijan lainnya.

Sehingga Armenia mengakui kehadiran di wilayah Azerbaijan adalah ilegal; bahwa tindakannya melanggar hukum internasional dan harus menimbulkan konsekuensi khusus, yaitu: tidak diakuinya situasi dengan ilegal; larangan bantuan atau bantuan dalam mempertahankannya; dan tanggung jawab masyarakat dunia untuk memastikan ketat kepatuhan oleh Armenia dengan kewajiban internasionalnya. Menurut pendapatnya di Namibia, Pengadilan Internasional juga memasukkan unsur fleksibilitas dalam doktrin non-pengakuan, dengan menyatakan bahwa: "Secara umum, tidak diakuinya administrasi Afrika Selatan atas Wilayah seharusnya tidak

26 Legal Consequences for States of the Continued Presence of South Africa in Namibia (South-West Africa) Notwithstanding Security Council Resolution 276 (1970), para. 124.

Uti Possidetis: Journal of International Law, Vol. 2, No. 3 (2021) 
mengakibatkan orang-orang Namibia kehilangan keuntungan apapun berasal dari kerjasama internasional.

Sudah jelas bahwa ekonomi ilegal dan kegiatan lainnya di wilayah pendudukan Azerbaijan telah berubah menjadi bisnis yang menguntungkan dan merupakan salah satu sumber pendapatan untuk Armenia dan rezim boneka yang didirikannya di sana. Armenia berusaha untuk memperpanjang pendudukan untuk mempertahankan kendali atas sumber daya mineral, pertanian dan air di wilayah tersebut dan yang diambil alih kekayaan mereka untuk keuntungan ekonominya sendiri. ${ }^{27}$

Di atas segalanya, upaya untuk mengubah komposisi demografis penduduk yang diduduki wilayah Azerbaijan ada sebelum pecahnya konflik secara artifisial meningkatkan jumlah orang Armenia di sana dan mencegah pemulangan ke rumah mereka dan harta benda ratusan ribu pengungsi internal Azerbaijan, bersama dengan perusakan dan perampasan properti, eksploitasi dan penjarahan sumber daya alam dan kekayaan lainnya di wilayah pendudukan sama sekali tidak dapat bersifat kemanusiaan dan konsisten dengan standar hak asasi manusia. Untuk itu, Wakil Tetap Azerbaijan berharap agar suratnya dapat diedarkan sebagai dokumen Majelis Umum, di bawah agenda 35, 40, 70, 72 dan 84, dan Dewan Keamanan.

27 Lihat the report of the Ministry for Foreign Affairs of the Republic of Azerbaijan entitled Illegal economic and other activities in the occupied territories of Azerbaijan (A/70/1016-S/2016/711, annex).

Uti Possidetis: Journal of International Law, Vol. 2, No. 3 (2021) 
Dengan demikian, pengabaian hukum oleh Armenia sebagai anggota PBB tidak dapat diterima dan memicu konsekuensi hukum bagi Armenia. Sebagai akibatnya, Armenia melanggar pasal 2 (4) Piagam PBB karena menggunakan larangan penggunaan kekuatan terhadap integritas teritorial Azerbaijan. PBB mendukung negara-negara anggota untuk tidak mengakui kemerdekaan negara-negara yang dibentuk di wilayah atau bagian dari wilayah yang diduduki. Penaklukan wilayah negara lain tidak dapat diterima, dan terlebih lagi penggunaan kekerasan sebagai metode untuk memperoleh wilayah itu tidak sah menurut hukum dan kebiasaan masingmasing.

\section{Penutup}

Berdasarkan pada studi kasus konflik Nagorno-Karabakh 2020 (Azerbaijan vs Armenia) terlihat adanya pelanggaran perjanjian internasional dalam hukum lingkungan internasional dan hukum humaniter internasional yang terjadi akibat konflik tersebut yang dapat dimintakan pertanggung jawaban secara internasional. Dalam prakteknya memang salah satu pihak yakni Azerbaijan tidak meratifikasi beberapa perjanjian internasional yang terkait kasus ini namun perlu diketahui bahwa Protokol Tambahan I Konvensi Jenewa Tahun 1977, protokol Jenewa 1925 dan Konvensi Stockholm telah diakui sebagai bentuk hukum kebiasaan internasional sehingga, bagi negara non-anggota seperti Azerbaijan tetap harus tunduk 
terhadap peraturan perang yang diatur dalam perjanjianperjanjian internasional tersebut.

Kemudian dalam kaitannya dengan pertanggungjawaban akibat konflik bersenjata, Armenia dan afiliasinya di wilayah pendudukan Azerbaijan bertanggung jawab atas tindakan pelanggaran internasional, yakni: Pertama, penggunaan kekuatan untuk memaksakan pemisahan de facto wilayah Nagorno-Karabakh dan distrik-distrik lainnya di Azerbaijan yang diduduki oleh Armenia dengan melanggar Piagam Perserikatan Bangsa-Bangsa. Kedua, pelanggaran selanjutnya atas kedaulatan dan keutuhan wilayah Azerbaijan. Ketiga, pembersihan etnis di wilayah pendudukan Azerbaijan, termasuk pendirian pemukiman dan penanaman pemukim etnis Armenia dengan pandangan untuk mengubah komposisi demografis wilayah tersebut. Keempat, pendapatan kotor pelanggaran hukum dan kebiasaan perang. Kelima, eksploitasi sumber daya alam wilayah pendudukan tanpa mempertimbangkan keunggulan kepentingan populasi dan perubahan cagar budaya daerah.

\section{Referensi}

\section{Instrumen Hukum}

United Nations General Assembly, Convention on The Prohibition of Military or Any Other Hostile of Environmental Modification Techniques (1976) 
Masalah Kemanusiaan hingga Lingkungan Hidup...

\section{Buku}

Adolf, Huala. Hukum Penyelesaian Sengketa Internasional. Jakarta: Sinar Grafika. Cetakan ketiga. 2008.

Ambarwati, Denny Ramdhany dan Rina Rusman. Hukum Humaniter Internasional Dalam Studi Hubungan Internasional. Jakarta: Raja Grafindo Persada. 2012.

Kusumaatmadja, Mochtar dan R. Agoes, Etty. Pengantar Hukum Internasional. Edisi Ke-2. Bandung: PT. Alumni. 2003.

Kusumaatmadja, Mochtar. Konvensi-Konvensi Palang Merah 1949. Bandung : PT Alumni. 2002.

\section{Artikel/Jurnal/Karya Ilmiah}

Convention on Prohibitions or Restrictions on the Use of Certain Conventional Weapons Which May be Deemed to be Excessively Injurious or to have Indiscriminate Effects. Geneva: ICRC. 2004.

Dinstein, Yoram. Protection of the Environment in International Armed Conflict. Max Planck Yearbook of United Nations Law. Volume 5. 2001.

Jacobsson, Marie G. International Law Commision: Preliminary report on the protection of the environment in relation to armed conflicts. 2014.

Nasution, Hanna Safira. Penyalahgunaan Wewenang Oleh Pejabat Diplomatik Dalam Melaksanakan Tugas Diplomatiknya Ditinjau Dari Aspek Hukum Internasional. Jurnal Ilmu Hukum, 2017

Papp, Daniel S. Contemporary International Relations : Frameworks for Understanding. Macmillan. 1988.

Sulaiman. Sengketa Bersenjata Non-Internasional. Jurnal Hukum dan Pembangunan 2000.

United Nations General Assembly, Convention on The Prohibition of Military or Any Other Hostile of Environmental Modification Techniques (1976).

Wartini, Sri. Perlindungan Lingkungan dalam Hukum Humaniter. Jurnal Hukum Ius Quia Iustum

Wulansari, Eka Martiana. Perlindungan Hukum Benda Budaya

Dari Bahaya Konflik Bersenjata. Disertasi. Universitas Pamulang. 2016. 
Wulansari, Eka Martiana. Perlindungan Hukum Benda Budaya Dari Bahaya Konflik Bersenjata. Disertasi. Universitas Pamulang. 2016.

Wyatt, J. Law Making at the Intersection of International Environmental Law, Humanitarian Law, and Criminal Law: The Issue of Damage to The Environment in International Armed Conflict. International Review of the Red Cross. 2010.

\section{Website}

Hizbullah Arief. Mengurai "Ecocide" untuk menyelamatkan Lingkungan? https://www.walhi.or.id/mengurai-ecocideuntuk-menyelamatkan-lingkungan www.mfa.gov.az/files/file/MFA Commentary to the remarks by Serzh Sargsyan.pdf. 